\title{
KAJIAN KADAR ASPAL HASIL EKSTRAKSI PENGHAMPARAN DAN MIX DESIGN PADA CAMPURAN ASPHALT CONCRETE WEARING COURSE (ACWC) GRADASI HALUS
}

\author{
Lusi Dwi Putri ${ }^{1}$, Sugeng Wiyono ${ }^{2}$, dan Anas Puri ${ }^{3}$ \\ ${ }^{1}$ Program Studi Teknik Sipil Universitas Lancang Kuning \\ 2 dan 3 Program Magister Teknik Sipil Universitas Islam Riau \\ lusidepe@yahoo.com
}

\begin{abstract}
ABSTRAK
Spesifikasi Umum 2010 revisi 2 (dua) Direktorat Jenderal Bina Marga pada poin dasar pembayaran menyebutkan bahwa sistem pembayaran pekerjaan aspal terpisah antara pembayaran aspal dan pembayaran agregat. Pembayaran aspal diberikan setelah dilakukan uji ekstraksi kadar aspal. Hasil ekstraksi kadar aspal yang telah dihampar biasanya kurang dari spesifikasi yang telah ditetapkan. Untuk itu perlu diketahui pengaruh pelaksanaan di asphalt mixing plant (AMP), asphalt finisher dan setelah dipadatkan di lapangan serta pengaruh kadar pori agregat dan filler terhadap kadar aspal hasil ekstraksi. Penelitian dilakukan pada laboratorium AMP PT. Lutvindo Wijaya Perkasa dan di lapangan. Uji ekstraksi kadar aspal menggunakan alat centrifuge extractor dengan pelarut bensin. Sample pengujian ekstraksi adalah campuran ACWC dari AMP, dari belakang asphalt finisher dan setelah dipadatkan di lapangan. Sample pengujian kadar pori berasal dari agregat quarry Ujung Batu, Bangkinang dan Solok. Berdasarkan hasil penelitian, kadar aspal rata-rata hasil ekstraksi di AMP sebesar 5,85\%, 5,80\% di belakang asphalt finisher dan 5,72\% dari hasil core. Kadar aspal ekstraksi untuk campuran di belakang asphalt finisher memiliki deviasi - $0,05 \%$ terhadap kadar aspal campuran di AMP. Kadar aspal hasil ekstraksi dari core memiliki deviasi - $0,08 \%$ terhadap kadar aspal campuran di belakang asphalt finisher. Kadar pori agregat quarry Ujung Batu 0,995\%, quarry Bangkinang 1,306\% dan quarry Solok 0,863\%. Hasil ekstraksi kadar aspal dipengaruhi oleh lokasi pengerjaan ACWC. Kadar aspal hasil ekstraksi semakin berkurang antara pengujian di AMP, di belakang asphalt finisher dan setelah dipadatkan di lapangan. Kadar aspal hasil ekstraksi juga dipengaruhi oleh kadar pori agregat dan filler yang dihasilkan. Dari pengujian kadar pori diperoleh semakin tinggi kadar pori agregat maka semakin berkurang kadar aspal hasil ekstraksi. Berdasarkan gradasi ekstraksi diperoleh semakin banyak filler maka semakin tinggi kadar aspal hasil ekstraksi.
\end{abstract}

Kata Kunci: Ekstraksi, Filler, Kadar Aspal, Kadar Pori

\section{PENDAHULUAN}

Terdapat perbedaan mendasar antara spesifikasi umum tahun 2006 dengan spesifikasi umum tahun 2010 revisi 2 (dua) tersebut yaitu pada poin dasar pembayaran. Pada spesifikasi umum tahun 2010 revisi 2 (dua) sistem pembayaran terpisah antara aspal dan agregat, sedangkan pada spesifikasi umum tahun 2006 sistem pembayarannya tidak terpisah. Dalam spesifikasi umum tahun 2010 revisi 2 (dua) subbab 6.3.7 poin 3d mengenai pengendalian mutu dan pemeriksaan di lapangan, disebutkan bahwa benda uji inti (core) tidak boleh digunakan untuk pengujian ekstraksi, uji ekstraksi harus dilakukan menggunakan benda uji campuran beraspal gembur yang diambil di belakang mesin penghampar. Hal ini menimbulkan keresahan dari pihak pelaksana, karena selalu terjadi pengurangan kadar aspal setelah ekstraksi sementara sistem pembayaran yang diterima terpisah antara agregat dengan aspal. Pihak pelaksana biasanya uji ekstraksi diambil dari uji inti (core). Hasil ekstraksi kadar aspal yang telah dihampar biasanya kurang dari spesifikasi yang telah ditetapkan sehingga hal ini menjadi permasalahan bagi pihak yang berkepentingan. Pada spesifikasi umum tahun 2010 revisi 2 (dua) subbab 6.3.3 poin 3c mengenai campuran juga disebutkan bahwa rumusan campuran kerja yang ditentukan dari campuran di laboratorium harus dianggap berlaku sementara sampai diperkuat oleh hasil percobaan pada instalasi pencampur aspal dan percobaan penghamparan dan pemadatan lapangan. Berdasarkan keterangan di atas perlu dikaji penyebab terjadinya pengurangan kadar aspal hasil 
ekstraksi pada instalasi pencampur aspal (asphalt mixing plant), saat penghamparan (di belakang asphalt finisher) dan setelah pemadatan lapangan (hasil core) serta pengaruh agregat yang digunakan.

Berpedoman kepada Spesifikasi Umum Direktorat Jenderal Bina Marga Tahun 2010 revisi 2 (dua) telah disyaratkan bahwa toleransi kadar aspal adalah $\pm 0,3 \%$ dari berat total campuran. Ini mengindikasikan bahwa kadar aspal memberi pengaruh besar bagi pelayanan lapis perkerasan jalan. Kadar aspal dalam campuran adalah banyaknya aspal dalam campuran beraspal yang diperoleh dengan cara ekstraksi menggunakan alat extractor. Untuk itu perlu dilakukan uji ekstraksi aspal. Berdasarkan keterangan di atas uji ekstraksi aspal mutlak dilakukan. Kadar aspal mempengaruhi durabilitas atau keawetan perkerasan aspal. Durabilitas dipengaruhi oleh tebalnya film atau selimut aspal, banyaknya pori dalam campuran aspal, kepadatan aspal dan kedap airnya campuran (Sukirman, 2003). Sifat mekanis dan sifat kimiawi dari agregat juga mempengaruhi daya lekat aspal dengan agregat. Sifat mekanis tergantung pada pori-pori dan absorbsi agregat, bentuk dan tekstur permukaan serta ukuran butiran, sedangkan sifat kimiawi salah satunya adalah pori-pori agregat. Agregat berpori dipergunakan untuk menyerap aspal, agregat dengan pori-pori yang banyak akan meyerap aspal yang banyak pula yang akan mengakibatkan lapisan aspalnya menjadi tipis pada permukaan batuan tersebut (Suryadharma dan Susanto, 2008).

Menurut spesifikasi campuran beraspal Direktorat Jenderal Bina Marga Tahun 2010 revisi 2 (dua), Laston (AC) terdiri dari tiga macam campuran, Laston Lapis Aus (AC-WC), Laston Lapis Pengikat (AC-BC) dan Laston Lapis Pondasi (AC-Base) dengan ukuran maksimum agregat masing-masing campuran adalah $19 \mathrm{~mm}, 25,4 \mathrm{~mm}, 3,75 \mathrm{~mm}$. Toleransi kadar aspal adalah $\pm 0,3 \%$ berat campuran.

\section{Ekstraksi kadar aspal}

Ekstraksi adalah proses pemisahan dua zat atau lebih dengan menggunakan pelarut yang tidak saling campur. Ada empat faktor penting yang secara dominan mempengaruhi laju ekstraksi yaitu sebagai berikut:

1. Ukuran partikel, semakin kecil ukuran solute, akan semakin mudah mengekstraksinya selain itu hendaknya ukuran butiran partikel tidak memiliki range yang jauh satu sama lain, sehingga setiap partikel akan menghabiskan waktu ekstraksi yang sama.

2. Pelarut (solvent), pelarut harus mempunyai selektivitas tinggi, artinya kelarutan zat yang ingin dipisahkan dalam pelarut harus besar, sedangkan kelarutan dari padatan pengotor kecil atau diabaikan. Viskositas pelarut sebaiknya cukup rendah sehingga dapat bersirkulasi dengan mudah.

3. Temperatur dalam banyak kasus, kelarutan material yang diekstraksi akan meningkat dengan naiknya temperatur, sehingga laju ekstraksi semakin besar. Koefisien difusi diharapkan meningkat dengan naiknya temperatur untuk memberikan laju ekstraksi yang lebih tinggi.

4. Agitasi fluida (solvent) akan memperbesar transfer material dari permukaan padatan ke larutan. Selain itu agitasi dapat mencegah terjadinya sedimentasi.

Rumus untuk menentukan kadar aspal hasil ekstraksi adalah sebagai berikut:

$H=\frac{A-(E+D)}{A} x 100 \%$

dengan:

$\mathrm{H}=$ kadar aspal sampel (\%)

$\mathrm{A}=$ berat sample sebelum ekstraksi (gram)

$\mathrm{D}=$ berat masa dari kertas filter (gram)

$\mathrm{E}=$ berat sample setelah ekstraksi (gram)

\section{Filler}

Filler adalah sekumpulan mineral agregat yang umumnya lolos saringan No. 200 yang mengisi di antara partikel beragregat kasar dalam rangka mengurangi besar rongga dan meningkatkan kerapatan dan stabilitas dari massa tersebut. Pengaruh filler adalah dalam adhesinya, oleh karena itu pengaruhnya sama halnya dengan penambahan kekentalan dari aspal murni. Filler berpengaruh dalam mekanismenya sebagai 
pendukung adhesi antara aspal dan agregat adalah secara mekanik dan kimia sekaligus. Penggunaan bahan pengisi dalam campuran beton aspal akan sangat mempengaruhi karakteristik beton aspal. karena akan mempengaruhi dalam proses pencampuran, penghamparan dan pemadatan. Di samping itu kadar dan jenis bahan pengisi juga akan berpengaruh terhadap sifat elastik campuran dan sensitifitas terhadap air (Totomihardjo dalam Fauna, 2006).

\section{METODOLOGI}

Penelitian ini dilaksanakan dengan menggunakan pengujian di laboratorium dan pengujian di lapangan. Tahapan pelaksanaan yang akan dilakukan meliputi persiapan bahan dan alat, pengujian yang dilakukan yaitu pengujian kadar pori agregat kasar (SNI 1969:2008), pengujian kadar pori agregat halus (SNI 1970:2008), pengujian Marshall (SNI 06-2489-1991), pengujian kadar aspal hasil ekstraksi (SNI 03-6894-2002) untuk benda uji di Asphalt Mixing Plant (AMP), benda uji dibelakang asphalt finisher dan benda uji setelah pemadatan lapangan (dari hasil core). Agregat yang digunakan quarry Ujung Batu. Agregat quarry Solok menggunakan data penelitian Fitridawati dan Muthia dan quarry Bangkinang menggunakan data sekunder. Data yang diperoleh harus memenuhi syarat menurut spesifikasi umum Bina Marga 2010 revisi 2 (dua).

\section{Cara analisis}

Kadar aspal hasil ekstraksi dari campuran ACWC yang diambil dari AMP dibandingkan dengan kadar aspal hasil ekstraksi dari campuran ACWC yang diambil dari belakang mesin penghampar (asphalt finisher) serta dari campuran ACWC setelah pemadatan di lapangan. Kemudian dianalisa trend kadar aspal hasil ekstraksi dari ketiga metode pelaksanaan tersebut. Kadar aspal hasil ekstraksi harus memenuhi kaidah yang disyaratkan dalam Spesifikasi Umum Bina Marga 2010 revisi 2 (dua). Hasil uji Marshall juga dianalisa apakah mutu campuran yang dihasilkan memenuhi kaidah yang disyaratkan dalam Spesifikasi Umum Bina Marga 2010 revisi 2 (dua). Kadar pori agregat berbagai quarry yaitu Bangkinang, Solok dan Ujung Batu dari masing-masing sample diuji sehingga didapatkan trend pengaruh kadar pori agregat terhadap kadar aspal hasil ekstraksi. Dari data gradasi hasil ekstraksi, diperoleh berat agregat yang lolos saringan \#200. Agregat tersebut dinalisa apakah beratnya lebih besar atau lebih kecil dari berat gradasi gabungan filler di JMF kemudian diperoleh trend pengaruh filler terhadap kadar aspal hasil ekstraksi.

\section{HASIL DAN PEMBAHASAN}

Hasil pengujian Marshall untuk campuran ACWC yang diambil di AMP, dari belakang asphalt finisher dan setelah pemadatan di lapangan (hasil core) dapat di lihat pada Tabel 1 sampai dengan Tabel 3. Hasil rekapitulasi perbandingan kadar aspal hasil ekstraksi antara mix design dengan asphalt finisher dan hasil core dapat dilihat pada Tabel 4. Dari hasil pengujian yang sudah dilakukan, pada Gambar 1 terlihat kecenderungan bahwa kadar aspal hasil ekstraksi dari pengujian ekstraksi kadar aspal dari AMP, asphalt finisher dan core nilainya semakin berkurang.

$$
\text { Rata-rata: } 5,85 \%>5,80 \%>5,72 \%
$$

sehingga dapat dibuat rumusan Kadar Aspal (KA) sebagai berikut:

KA mix design $>$ KA saat penghamparan $>$ KA setelah pemadatan

Tabel 1. Hasil Pengujian Marshall Campuran ACWC dari AMP

\begin{tabular}{|c|c|c|c|c|c|}
\hline \multirow{2}{*}{ No } & \multirow{2}{*}{ Benda Uji } & \multicolumn{2}{|c|}{ Stability (Kg) } & \multirow{2}{*}{ Flow $(\mathrm{mm})$} & \multirow{2}{*}{$\begin{array}{c}\text { Hasil Bagi Marshall } \\
\mathrm{Kg} / \mathrm{mm}\end{array}$} \\
\hline & & Dibaca & Di Sesuaikan & & \\
\hline 1 & Sampel-1 & 55 & 1189,65 & 3,70 & 321,53 \\
\hline 2 & Sampel-2 & 53 & 1146,39 & 3,50 & 327,54 \\
\hline 3 & Sampel-3 & 54 & 1168,02 & 3,50 & 333,72 \\
\hline 4 & Sampel-4 & 52 & 1124,76 & 3,40 & 330,81 \\
\hline 5 & Sampel-5 & 53 & 1146,39 & 3,50 & 327,54 \\
\hline 6 & Sampel-6 & 56 & 1211,28 & 3,70 & 327,37 \\
\hline \multicolumn{3}{|c|}{ Rata-rata } & 1164,42 & 3,55 & 328,09 \\
\hline \multicolumn{3}{|c|}{ Syarat spesifikasi } & Min 800 & Min 3 & Min 250 \\
\hline
\end{tabular}


Tabel 2. Hasil Pengujian Marshall Campuran ACWC dari Asphalt Finisher

\begin{tabular}{|c|c|c|c|c|c|}
\hline \multirow{2}{*}{ No } & \multirow{2}{*}{ Benda Uji } & \multicolumn{2}{|c|}{ Stability $(\mathrm{Kg})$} & \multirow{2}{*}{ Flow (mm) } & \multirow{2}{*}{$\begin{array}{c}\text { Hasil Bagi Marshall } \\
\mathrm{Kg} / \mathrm{mm}\end{array}$} \\
\hline & & Dibaca & Di Sesuaikan & & \\
\hline 1 & Sampel-1 & 50 & 1081,50 & 3,40 & 318,09 \\
\hline 2 & Sampel-2 & 51 & 1103,13 & 3,50 & 315,18 \\
\hline 3 & Sampel-3 & 50 & 1081,50 & 3,40 & 318,09 \\
\hline 4 & Sampel-4 & 49 & 1059,87 & 3,50 & 302,82 \\
\hline 5 & Sampel-5 & 52 & 1124,76 & 3,50 & 321,36 \\
\hline \multirow[t]{3}{*}{6} & Sampel-6 & 51 & 1103,13 & 3,40 & 324,45 \\
\hline & \multicolumn{2}{|c|}{ Rata-rata } & 1092,32 & 3,45 & 316,66 \\
\hline & \multicolumn{2}{|c|}{ Syarat spesifikasi } & Min 800 & $\operatorname{Min} 3$ & $\operatorname{Min} 250$ \\
\hline
\end{tabular}

Tabel 3. Hasil Pengujian Marshall Campuran ACWC dari Hasil Core

\begin{tabular}{|c|c|c|c|c|c|}
\hline \multirow{2}{*}{ No } & \multirow{2}{*}{ Benda Uji } & \multicolumn{2}{|c|}{ Stability $(\mathrm{Kg})$} & \multirow{2}{*}{ Flow (mm) } & \multirow{2}{*}{$\begin{array}{l}\text { Hasil Bagi Marshall } \\
\mathrm{Kg} / \mathrm{mm}\end{array}$} \\
\hline & & Dibaca & Di Sesuaikan & & \\
\hline 1 & Sampel-1 & 47 & 1016,61 & 3,20 & 317,69 \\
\hline 2 & Sampel-2 & 44 & 951,72 & 3,30 & 288,40 \\
\hline 3 & Sampel-3 & 45 & 973,35 & 3,20 & 304,17 \\
\hline 4 & Sampel-4 & 48 & 1038,24 & 3,40 & 305,36 \\
\hline 5 & Sampel-5 & 46 & 994,98 & 3,40 & 292,64 \\
\hline \multirow[t]{3}{*}{6} & Sampel-6 & 48 & 1038,24 & 3,40 & 305,36 \\
\hline & \multicolumn{2}{|c|}{ Rata-rata } & 1002,19 & 3,32 & 302,27 \\
\hline & \multicolumn{2}{|c|}{ Syarat spesifikasi } & Min 800 & $\operatorname{Min} 3$ & Min 250 \\
\hline
\end{tabular}

Tabel 4. Rekapitulasi Perbandingan Kadar Aspal Hasil Ekstraksi

\begin{tabular}{|c|c|c|c|c|c|c|c|c|c|}
\hline \multirow[b]{2}{*}{ No } & \multirow[b]{2}{*}{ Benda Uji } & \multicolumn{4}{|c|}{ Kadar Aspal Hasil Ekstraksi } & \multirow{2}{*}{$\begin{array}{c}\text { Kadar } \\
\text { aspal } \\
\text { JMF (\%) }\end{array}$} & \multirow[b]{2}{*}{$\begin{array}{c}\text { עeviasi } \\
(\%)\end{array}$} & \multirow[b]{2}{*}{$\begin{array}{l}\text { I Uicianisı } \\
\text { Spek (\%) }\end{array}$} & \multirow[b]{2}{*}{ Keterangan } \\
\hline & & $\begin{array}{l}\text { AMP } \\
(\%)\end{array}$ & $\begin{array}{c}\text { Finisher } \\
(\%)\end{array}$ & $\begin{array}{l}\text { Core } \\
(\%)\end{array}$ & $\begin{array}{c}\text { Rata-rata } \\
(\%)\end{array}$ & & & & \\
\hline 1 & Sampel -1 & 5,89 & 5,84 & 5,74 & 5,82 & 5,80 & 0,02 & $\pm 0,3$ & Memenuhi \\
\hline 2 & Sampel -2 & 5,91 & 5,86 & 5,75 & 5,84 & 5,80 & 0,04 & $\pm 0,3$ & Memenuhi \\
\hline 3 & Sampel -3 & 5,76 & 5,73 & 5,71 & 5,73 & 5,80 & $-0,07$ & $\pm 0,3$ & Memenuhi \\
\hline 4 & Sampel -4 & 5,88 & 5,71 & 5,72 & 5,77 & 5,80 & $-0,03$ & $\pm 0,3$ & Memenuhi \\
\hline 5 & Sampel -5 & 5,80 & 5,80 & 5,68 & 5,76 & 5,80 & $-0,04$ & $\pm 0,3$ & Memenuhi \\
\hline \multirow[t]{2}{*}{6} & Sampel -6 & 5,87 & 5,88 & 5,70 & 5,82 & 5,80 & 0,02 & $\pm 0,3$ & Memenuhi \\
\hline & Rata-rata & 5,85 & 5,80 & 5,72 & 5,79 & 5,80 & $-0,01$ & & \\
\hline
\end{tabular}




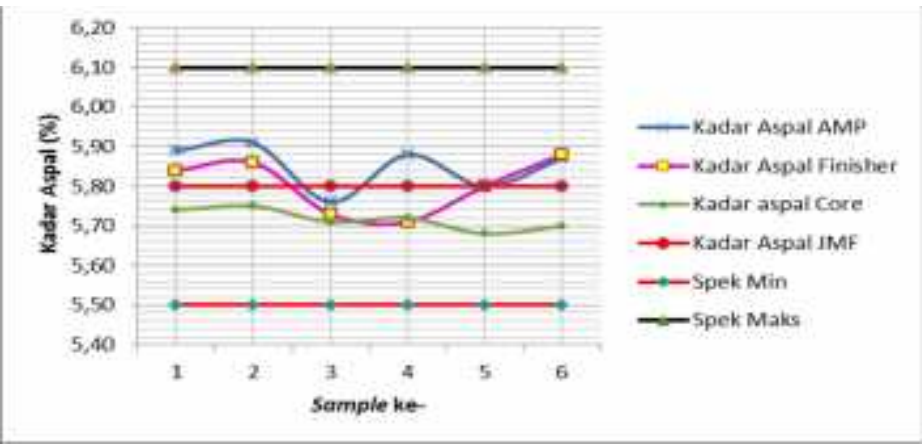

Gambar. 1 Kadar aspal hasil ekstraksi dari AMP, finisher dan hasil core

Pada saat pengujian di AMP, nilai kadar aspal hasil ekstraksi sebesar 5,85\%. Pada saat penghamparan di lapangan nilai kadar aspal hasil ekstraksi sebesar 5,80\% deviasi - 0,05\% dari kadar aspal pada saat pengujian di AMP. Hal ini dikarenakan waktu yang diperlukan atau lamanya perjalanan pengangkutan dari AMP ke lokasi kegiatan sehingga aspal yang ada cendrung meresap ke pori-pori agregat selama perjalanan pengangkutan campuran ACWC. Setelah pemadatan di lapangan, dilakukan pengujian kadar aspal hasil ekstraksi dari hasil core. Diperoleh nilai kadar aspal hasil ekstraksi sebesar 5,72\% dengan deviasi - 0,08\% dari kadar aspal hasil ekstraksi saat penghamparan. Hal ini dikarenakan umur jalan sejak dihamparkan sampai benda uji dari hasil core diperoleh adalah 1(satu) minggu sehingga proses pemadatan atau repetisi beban mengakibatkan kadar aspal cenderung meresap ke pori-pori agregat akibatnya nilai kadar aspal hasil ekstraksi menjadi berkurang. Porositas agregat merupakan ruang kosong atau besarnya kadar pori agregat. Kadar pori agregat ditentukan oleh banyaknya air yang diserap oleh pori tersebut (Toruan, 2013). Hal ini dapat diartikan bahwa kadar pori agregat sama nilai besarannya dengan penyerapan air oleh agregat tersebut. Dari Gambar 2 terlihat trend bahwa kadar pori agregat mempengaruhi kadar aspal yang terserap. Kadar aspal hasil ekstraksi perkerasan cenderung menurun seiring dengan peningkatan kadar pori agregat. Hal ini disebabkan karena aspal meresap atau terabsorbsi ke dalam pori agregat. Semakin besar kadar pori agregat maka semakin banyak aspal yang terabsorbsi.

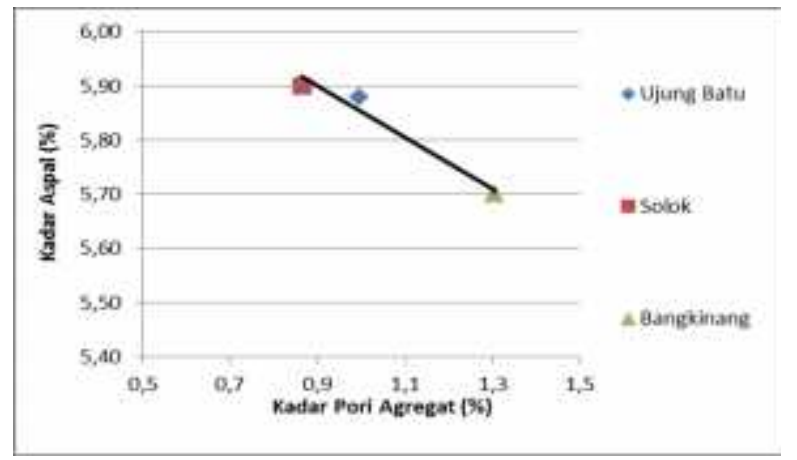

Gambar 2. Hubungan kadar pori dengan kadar aspal hasil ekstraksi

Grafik yang mewakili arti fisik di lapangan serta korelasi nilai $\mathrm{R}^{2}$ dapat dilihat pada Gambar 3. Semakin banyak filler maka kadar aspal semakin tinggi, hal ini dikarenakan filler yang ada menaikkan bidang kontak atau luas permukaan agregat yang menambah tebal film aspal yang menyelimuti agregat tersebut.

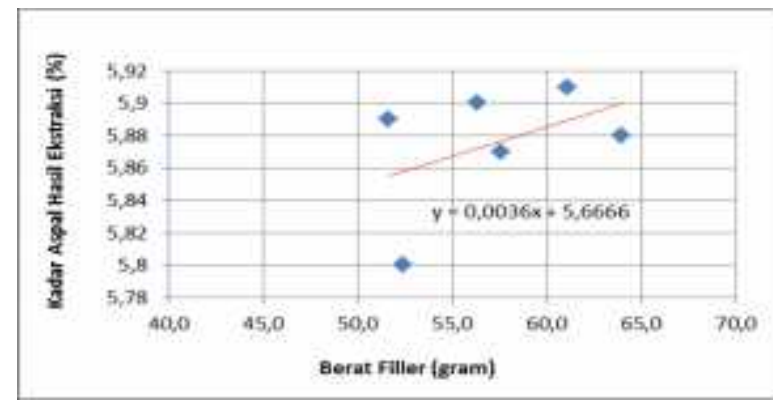

Gambar 3. Hubungan filler dengan kadar aspal hasil ekstraksi di AMP 


\section{KESIMPULAN}

Berdasarkan hasil dan pembahasan dapat disimpulkan sebagai berikut:

1. Pelaksanaan campuran ACWC di AMP, asphalt finisher dan core memberi pengaruh terhadap kadar aspal hasil ekstraksi, dimana kadar aspal hasil ekstraksi nilainya semakin berkurang antara $A M P$, asphalt finisher dan core. Dari penelitian diperoleh kadar aspal rata-rata hasil ekstraksi di AMP $5,85 \%$, di belakang asphalt finisher $5,80 \%$, dari hasil core 5,72\%. Kadar aspal campuran di belakang asphalt finisher memiliki deviasi $-0,05 \%$ terhadap kadar aspal campuran di AMP. Kadar aspal hasil ekstraksi dari hasil core memiliki deviasi -0,08\% terhadap kadar aspal campuran di belakang asphalt finisher. Berdasarkan hasil uji Marshall campuran ACWC yang di ambil di AMP, di belakang asphalt finisher dan hasil core sudah memenuhi standar menurut Spesifikasi Umum Bina Marga 2010 revisi 2 (dua).

2. Kadar pori agregat mempengaruhi kadar aspal hasil ekstraksi, semakin tinggi kadar pori agregat maka semakin berkurang kadar aspal hasil ekstraksi. Dari pengujian diperoleh kadar pori agregat quarry Ujung Batu 0,995\%, quarry Bangkinang 1,306\% dan quarry Solok 0,863\%.

3. Filler mempengaruhi kadar aspal hasil ekstraksi, semakin banyak filler maka semakin tinggi kadar aspal hasil ekstraksi. Dari hasil penelitian diperoleh kadar filler menjadi bertambah setelah di ekstraksi. Gradasi agregat berubah menjadi lebih halus dari gradasi semula. Kelebihan filler tersebut diduga berasal dari agregat yang mengalami degradasi.

\section{Saran}

Berdasarkan kesimpulan dapat disarankan sebagai berikut:

1. Diharapkan ada penelitian lain yang mengkaji pengaruh pemadatan terhadap hasil ekstraksi.

2. Terkait dengan uji filler yang selama ini tidak bisa dibuktikan disarankan agar bisa dipertimbangkan bahwa filler tersebut sudah terabsorbsi oleh aspal.

3. Terkait dengan hasil penelitian disarankan kepada pihak yang terkait bahwasanya Spesifikasi Umum Bina Marga 2010 revisi 2 (dua) ini bisa diterima

\section{UCAPAN TERIMA KASIH}

Penulis ingin menyampaikan penghargaan dan ucapan terima kasih sebesar-besarnya kepada:

1. Bapak Prof. Dr. H. Detri Karya, S.E., M.A. selaku Rektor Universitas Islam Riau beserta jajaran atas izin melaksanakan penelitian dan kemudahan lainnya di lokasi penelitian.

2. Pimpinan, karyawan, kepala labor beserta staf labor PT. Lutvindo Wijaya Perkasa Pekanbaru yang telah memberikan ilmu dan fasilitas untuk penelitian;

3. Muthia Anggraini S.T., M.T. dan Fitridawati Soehardi S.T., M.T. untuk data penelitian agregat quarry Solok.

\section{DAFTAR PUSTAKA}

Anggraini, Muthia, 2014, "Kajian Kadar Aspal Hasil Ekstraksi Penghamparan Campuran ACWC Bergradasi Kasar Dengan Mix Design” Tesis, Program Magister Teknik Sipil Universitas Islam Riau

Departemen Pekerjaan Umum, Standar Nasional Indonesia, "Cara Uji Berat Jenis dan Penyerapan Air Agregat Kasar”, SNI 1969-2008 Agregat Halus”, SNI 1970-2008

Standar Nasional Indonesia. "Cara Uji Berat Jenis dan Penyerapan Air , Standar Nasional Indonesia. "Metode Pengujian Kadar Aspal Dari Campuran Beraspal Dengan Cara Sentrifus”, SNI 03-6894-2002

Alat Marshall”, SNI 06-2489-1991 
Annual Civil Engineering Seminar 2015, Pekanbaru

ISBN : 978-979-792-636-6

Direktorat Jenderal Bina Marga, 2010,"Spesifikasi Umum Binamarga 2010 Revisi 2", Kementrian Pekerjaan Umum Direktorat Jenderal Bina Marga, Jakarta,2010

Fauna dan Mukhlis, 2006, "Pengaruh Penggunaan Filler Portland Cement Dalam Campuran Asphalt Concrete (AC) Terhadap Sifat Marshall dan Nilai Struktural", Jurnal Ilmiah Poli Rekayasa Vol.2 No.1 pp. 1-13, Politeknik Negeri Padang

Soehardi, Fitridawati, 2014, "Kajian Perbandingan Kadar aspal Hasil ekstraksi Campuran ACWC Gradasi Kasar Dengan Cairan Ekstraksi Menggunakan Bensin” Tesis, Program Magister Teknik Sipil Universitas Islam Riau

Sukirman, Silvia, 2003, “Beton Aspal Campuran Panas”, Jakarta: Granit

Suryadharma dan Susanto, 2012, “Rekayasa Jalan Raya”, Universitas Atmajaya Yogyakarta

Toruan, Armin, 2013, "Pengaruh Porositas Agregat Terhadap Berat Jenis Maksimum Campuran", Jurnal Sipil Statik. Volume 1, No 3 pp.190-195, Fakultas Teknik Sipil Universitas Samratulangi 